\title{
Governance Responsiveness in Health Services in the Regency/City of Gorontalo Province
}

\author{
Sangkala $^{1}, \mathrm{~S}$ Lambali $^{2}$, L Atmansyah ${ }^{3}$, A Hans $^{4}$ \\ 1,2,3,4 Universitas Hasanuddin, Makassar \\ $\underline{1 \text { sangkalarewa@gmail.com, }}, \underline{2}$ surlam2006@yahoo.co.id, ${ }^{3}$ lutfiasyah@yahoo.com, \\ 4amril.hans@unhas.ac.id
}

\begin{abstract}
Responsive governments need to be aware that one source of increasing public demand is a rights-based approach to the implementation of public services. When a government is deemed unresponsive to people's needs, trust in the government decreases and can even threaten political and social stability. One of the public services is health services. Health services are very important in assessing the performance of local governments. Gorontalo Province is still a new province, a division of North Sulawesi Province. The economic growth rate of Gorontalo province is $6.74 \%$ while North Sulawesi Province is $6.32 \%$. For the national average, the growth of Gorontalo Province is above the national economic growth of $5.1 \%$. But the results of the assessment show that the average level of accountability of the government in the Regency / City of Gorontalo Province is still in the range of the $\mathrm{CC}$ level. Observing these conditions, the results of the study show that the level of responsiveness of the district / city governments in Gorontalo Province is still low in the aspect of health services. As for the details of the results of the research on the implementation of health services in the districts / cities of Gorontalo province are still low as follows: (1) Hospitals in Gorontalo City, Gorontalo Regency and North Gorontalo District surveyed are six hospitals. the survey results show that the efficiency and effectiveness aspects of the hospital in response to patient needs are still low. (2) The survey results on aspects of fulfilling the rights of patients in six hospitals are also still in the low category, resulting in a decrease in the level of public trust in the hospital. (3) The results of the survey on the competence aspects of health workers in serving are good but the ethics of public services are still low. (4) The results of the survey on aspects of patient involvement in participating in increasing hospital responsiveness have not shown satisfactory results, because patients are considered not part of the hospital. 5) The survey results show that aspects of health service delivery based on Information Technology are not responsive because the use of Information Technology is still partial.
\end{abstract}

Keywords : Health Services, Responsiveness, Local Government

\section{INTRODUCTION}

Responsive governance requires public servants to act in excess of orders and be proactive. To strengthen responsiveness to public services, capacity building in areas such as innovation, customer and citizen focus, collaboration, project management, financial 
management and negotiations, among others, are needed. Most important is, there is a need to instill commitment in serving citizens.

Decentralized governance, in particular, is very instrumental in encouraging development at the local community level. Local government can achieve better results by involving local communities because it is more aligned with local needs and local solutions and is likely to address them.

Observing the development of both the concepts and experiences of governance practices related to governance responsiveness in Gorontalo Province. Gorontalo Province which consists of 6 (six) regencies/cities is the result of the division of North Sulawesi Province is seen as a region whose economic growth is more advanced than the parent Province (North Sulawesi). But in the aspect of responsiveness and accountability are still at a level that is still low. The average level of government accountability in 2017 data is still in the CC level range [1]. This study identifies the responsiveness variable in public services, especially in the health sector.

\section{RESEARCH METHOD}

This research was conducted in hospitals in 4 regencies/cities in Gorontalo Province, namely Gorontalo City, Gorontalo Regency, North Gorontalo Regency, and Bone Bolango Regency. The sampling technique used was purposive sampling. The number of samples obtained was 240 respondents. While the data analysis technique used is descriptive statistical analysis techniques. Quantitatively, the description of the data is based on the calculation of the frequency of the scores for each alternative questionnaire answer, so that a percentage and an average score of respodent answers are obtained from each variable, dimension and indicator. To get the range of interpretation of each score (1 to 4 ) the range formula is used as follows:

Range $=\frac{\text { Highest Score }- \text { Lowest Score }}{\text { Number of Scores }}$

Information :

Highest score $\quad: 4$

The lowest score $\quad: 1$

Total score $: 4$

Values Range $\quad=\frac{4-1}{4}=0,75$

From these results the range of interpretations is obtained as follows

\begin{tabular}{ll}
\hline Range & Interpretation \\
\hline $1,00-1,75$ & Not Good \\
\hline $1,76-2,50$ & Poor \\
\hline $2,51-3,25$ & Good \\
\hline $3,26-4,00$ & Very Good \\
\hline
\end{tabular}

\section{RESULTS AND DISCUSSION}

In this study, there are 5 (five) variables used in examining governance responsiveness in Gorontalo Province related to health services. The 5 variables are: 1) Efficiency and Effectiveness of Responsive Governance; 2) Meeting Increased Demand and Declining Public 
Trust; 3) Competent, Differential and Ethical Public Servants; 4) Citizen Engagement and Community Empowerment; and 5) Multiple Service Channels. To be more clear, the average indicator scores are broken down for each variable as follows:

Table-1. Average Score Efficiency and Effectiveness Responsive Governance Variables

\begin{tabular}{llll}
\hline No & Indicator & Score & Interpretation \\
\hline 1 & Responsive Effectiveness of Governance & 2,54 & Good \\
\hline 2 & Responsive Efficiency Governance & 2,53 & Good \\
\hline 3 & Hospital View of Patients & 2,76 & Good \\
\hline 4 & Hospital Organizational Functions in Carrying Out Tasks & 2,66 & Good \\
\hline 5 & Hospital Staff Competencies & 2,76 & Good \\
\hline 6 & Implementing Strategy & 2,34 & Poor \\
\hline 7 & Hospital Efficiency in Policy Implementation & 2,01 & Poor \\
\hline 8 & Hospital Responsiveness Level & 2,59 & Good \\
\hline 9 & Hospital Staff Competency Level & 2,87 & Good \\
\hline 10 & Hospital Staff Ethics in Supporting Hospitals & 2,69 & Good \\
\hline Average Scoce Total & 2,58 & Good
\end{tabular}

Source: Processed from primary data, 2019

From the table above (table-1), it is known that from 10 indicators on the efficiency and effectiveness variables in hospital services in 4 regions of Gorontalo Province, namely Gorontalo City, Gorontalo Regency, North Gorontalo Regency and Bonebolang0 Regency show an average score of 2, 58 responsive categorized as "Good" with a range of interpretations $(2,51-3,25)$.

Table-2. Average Variable Score Increase in Demand and Decrease in Public Confidence

\begin{tabular}{llll}
\hline No & Indicator & Score & Interpretation \\
\hline 1 & Rights-Based Approach in Services & 2,75 & Good \\
\hline 2 & $\begin{array}{l}\text { Government in Responding to the Rights of } \\
\text { Female Patients }\end{array}$ & 2,57 & Good \\
\hline 3 & $\begin{array}{l}\text { Communication Access to the Head of } \\
\text { Hospital }\end{array}$ & 1,72 & Not Good \\
\hline 4 & $\begin{array}{l}\text { Patient Involvement in Hospital Policy } \\
\text { Development }\end{array}$ & 1,89 & Poor \\
\hline 5 & $\begin{array}{l}\text { Patient Involvement When the Policy Has } \\
\text { Decided }\end{array}$ & 2,00 & Poor \\
\hline Average Scoce Total & 2,19 & Poor \\
\hline Source: Processed fromprimary
\end{tabular}

Source: Processed from primary data, 2019

In table-2, for the average score of the variable increase in demand and decrease in public confidence, the average score of 2.19 is obtained under the category of "Poor" in which the respondent is generally dissatisfied with the services of the hospital in Gorontalo Province.

Table-3. Average Score of Competent Variables, Differences and Ethics of Public Services 


\begin{tabular}{|c|c|c|c|}
\hline No & Indicator & Score & Interpretation \\
\hline 1 & Serving Patients Based on Laws & 2,78 & Good \\
\hline 2 & Employee Code of Ethics in Services & 2,74 & Good \\
\hline 3 & Hospital Service Standards & 2,59 & Good \\
\hline 4 & Professional Level of Employees & 2,64 & Good \\
\hline 5 & $\begin{array}{l}\text { Special Competencies of Employees to be } \\
\text { Responsive }\end{array}$ & 3,24 & Very Good \\
\hline 6 & Fair Attitude of Hospitals in Services & 2,80 & Good \\
\hline 7 & Active Employees in Serving & 2,64 & Good \\
\hline 8 & Hospital Staff Capacity in Serving & 2,59 & Good \\
\hline 9 & Hospital Services Process and Procedures & 2,67 & Good \\
\hline \multicolumn{2}{|c|}{ Average Scoce Total } & 2,74 & Good \\
\hline
\end{tabular}

Source: Processed from primary data, 2019

For the Compentent variable, the Differences and Ethics of Public Services in table-3 above shows the results that hospital services in 4 districts in Gorontalo Province have been categorized as "Good" with an average score of 2.74 .

Table-4. Average Variable Score of Citizens and Community Empowerment

\begin{tabular}{llll}
\hline No & Indicator & Score & Interpretation \\
\hline 1 & Hospital Staff Behavior & 2,66 & Good \\
\hline 2 & Responsibilities of Hospital Personnel & 2,71 & Good \\
\hline 3 & Hospitals Empower & 1,92 & Poor \\
\hline 4 & Community Opportunity to Participate & 1,79 & Poor \\
\hline 5 & The Hospital Involved Patients Politically & 1,90 & Poor \\
\hline \multirow{2}{*}{ Average Scoce Total } & \multirow{2}{*}{ Hospital-Patient Conflict Resolution } & 1,87 & Poor \\
\hline
\end{tabular}

Source: Processed from primary data, 2019

Citizen and Community Empowerment Variables in table-4 show the results of "Poor" where the score obtained on this variable only reached 2.14. The low score is due to several low indicator values such as the hospital in empowering the community or patients, as well as the low resolution of conflicts between the hospital and the patient.

Table-5. Average Variable Scores of Various Service Delivery Channels

\begin{tabular}{llll}
\hline No & Indicator & Score & Interpretation \\
\hline 1 & $\begin{array}{l}\text { Ability in the use of information technology } \\
\text { (IT) }\end{array}$ & 2,28 & Poor \\
\hline 2 & The Use of IT in Access to Services & 2,26 & Poor \\
\hline 3 & IT Able to Provide Information & 2,21 & Poor \\
\hline 4 & IT in Administrative Efficiency & 2,21 & Poor \\
\hline 5 & IT Operations in the Hospital Work & 2,22 & Poor \\
\hline 6 & IT in increasing responsiveness & 2,21 & Poor \\
\hline 7 & IT in Improving Patient Access & 2,19 & Poor \\
\hline
\end{tabular}




\begin{tabular}{lcc}
\hline Average Scoce Total & 2,23 & Poor \\
\hline Source: Processed from primary data, 2019 & &
\end{tabular}

For the last variable, namely service delivery variable which has various channels, in general is still classified as a low category with an average score of 2.23 . This shows that the hospital is "Poor" in the use of information technology (IT) in providing health services.

Table-6. Average Score of All Variables

\begin{tabular}{lllll}
\hline No & Variable & Score & Interpretation \\
\hline 1 & $\begin{array}{l}\text { Variable Efficiency and Effectiveness } \\
\text { Responsive Governance }\end{array}$ & 2,58 & Good \\
\hline 2 & $\begin{array}{l}\text { Variable Increase in Demand and Decrease in } \\
\text { Public Confidence }\end{array}$ & 2,19 & Poor \\
\hline 3 & $\begin{array}{l}\text { Competent Variables, Differences and Ethics of } \\
\text { Public Services }\end{array}$ & 2,74 & Good \\
\hline 4 & $\begin{array}{l}\text { Citizen Variables and Community } \\
\text { Empowerment }\end{array}$ & 2,14 & Poor \\
\hline $5 \quad \begin{array}{l}\text { Variable Scores of Various Service Delivery } \\
\text { Channels }\end{array}$ & 2,23 & Poor \\
\hline Rata-rata skor dan persentase & 2,38 & Poor \\
\hline Source: Processed from primary data, 2019 & &
\end{tabular}

Based on the average value of each variable, then in Table- 6 it can be concluded that the level of responsiveness of the Gorontalo government in public services in the health sector carried out by hospitals which are in districts and cities is not good where the scores obtained on average of all these variables only reached a value of 2.38. Based on the acquisition of these values at the same time shows that the assessment of the community requires concrete action from each of the parties concerned to improve these conditions. In the next review, this study explores why community assessments of existing health services in hospitals are still classified as poor.

Measuring the effectiveness and efficiency of government responsiveness is no exception services in the health sector is very important especially when associated with government attributes that are classified as good governance. Florina states that efficiency and effectiveness are key features of good governance, where the public sector is seen as responsible for finding ways to make the best use of resources, human, material, financial and others[2]. The statement from Florina is in line with the view of UNDP which states that effectiveness and efficiency are the processes and results of the production of institutions to meet the needs by making the best use of resources[3].

The condition of the level of effectiveness and efficiency of public service responsiveness in the health sector in Gorontalo province which is still not optimal shows that the management of health care institutions is not good. Moreover, the second aspect of hospital responsiveness variable as the spearhead of health services is considered by the public to be still poor, namely the variable of increasing demand and decreasing public trust. In the perspective of responsive governance, fulfillment of public demand based on rights becomes very important[4]. Efficient and effective responses to people's real needs require public engagement to identify and articulate their needs. This is guaranteed in the Universal 
Declaration of Human Right which states that everyone has the right to take part in the government of his country, directly or through freely chosen representatives.

Public trust in the management of the public sector is very important for the implementation of good governance. Welch et al state that trust in government is usually measured by the subjective assessment of citizens based on their experience[5]. They hope that citizens' trust will arise if they touch government competence, reliability and honesty when meeting the needs of citizens. Thus good governance is when the government is able to interact with citizens and anyone who will be involved in the governance process. In the survey results it was revealed that all the variables or determinants which are referred to as responsive governance are still not optimal, especially the public trust variable which is still low. This of course must try to show the level of public confidence because it is still low.

The variable of community empowerment that should be the responsibility of employees, patient empowerment, community opportunities to participate, conflict resolution between patients and hospitals is not good in the eyes of the community. This shows that the involvement of the community in the formulation of programs and policy-making has not been carried out properly. This is because the existing employees have not provided opportunities and opportunities for the community to participate have not yet been carried out. Quality of service is considered good if there is no conflict between the service officer and the community. But the case at the Gorontalo hospital according to the community's recognition actually felt the hospital was unable to resolve the conflicts that occurred between the hospital management with the customer.

According to Sheedy, the involvement of citizens, especially in the distribution of power, providing information, and mutual respect between the government and citizens is very important[6]. Their involvement can be judged by how the community and community are involved and play an effective role in decision making[7]. Based on Bassler's statement it can be concluded that the condition of public services in the field of responsive health with a measure of the extent to which the level of community participation in decision making is still low while showing that responsive health services in Gorontalo hospitals are also not good. Demand that all citizens regardless of sex, age, agaram, ethical, origin, socioeconomic status, have the opportunity to participate in the decision making process that will affect their lives going forward. Community assessment related to aspects of community empowerment in health services, especially in the participation of decision making in the Gorontalo provincial hospital which is still low indicates the need for leadership commitment to open the space as evidenced in the form of various decision-making activities to be urgent.

Community involvement in decision making can be measured by the extent to which the hospital provides enough space and the role of the community. These involved both in the form of the process of defining the problem, identifying solutions to each problem, and their involvement in mapping the priorities of the actions to be taken and how the utilization of the resources that go with them. Rowe and Frewer divide the form of community involvement in policy making and decisions, namely involvement in the form of public communication, public consultation, and public participation[8]. When referring to the views of Rowe and Frewer, the hospital in Gorontalo province has not been done so that if the community assessment related to community involvement in the policy making and decision making process is still low, it also shows that the practice of public services has not been responsive.

The value of service delivery in various channels is also not good, especially related to aspects of the ability to use information technology in accessing services, information technology provided by hospitals has not been able to provide information, administration efficiency using information technology is still low, operationalization of hospital work in the 
use of information technology still not good, the use of hospital information technology in building responsiveness is still and also the use of information technology for use by patients in accessing health service information is also not good.

The substance of responsive government can be seen from the extent of the government's seriousness in establishing, developing and strengthening facilities and infrastructure as well as the use of information technology. Because information technology is able to accelerate and expand community access simultaneously in accessing both information and health services. United Nations E-Government Survey, states that the use of information technology in public services, citizens can make choices according to their needs and circumstances and receive information and services that are consistent across channels that result in an increase in their satisfaction and trust in government[9]. Thus the use of information technology in public services, the government at the same time gets two advantages, namely creating more efficient and effective public services, also can increase citizens' trust in the government. In this regard, the Gorontalo provincial government with its regencies and cities and hospitals lacks a positive rating because they have not yet developed an information technology based public service system. Still facing a weak budget for the procurement of information technology facilities and infrastructure, insufficient workers have expertise in the field of information technology. Because it still requires political commitment from leaders in all lines where indeed the survey results show it is still low.

\section{CONCLUSIONS}

The level of responsiveness of regency/city governments in the Gorontalo Province region in carrying out the function of providing services to the public in the field of health carried out by all hospitals is not good.

\section{REFERENCES}

[1] Kementerian Pendayagunaan Aparatur Negara dan Reformasi Birokrasi, "Laporan Akuntabilitas Instansi Pemerintah," Jakarta, 2017.

[2] P. Florina, "Elements on the Efficiency and Effectiveness of the Public Sector," Ovidius Univ. Ann. Econ. Sci. Ser., vol. XVII, no. 2, pp. 313-319, 2017.

[3] U. N. D. Programme, "Human Development Report, 1997," New York, 1997.

[4] United Nations, "World Public Sector Report 2015: Responsive and Accountable Public Governance," 2015.

[5] E. W. Welch, C. C. Hinnant, and M. J. Moon, "Linking citizen satisfaction with egovernment and trust in government," J. Public Adm. Res. Theory, vol. 15, no. 3, pp. 371-391, 2005, doi: 10.1093/jopart/mui021.

[6] A. Sheedy, P. Mackinnon, S. Pitre, and J. Watling, Handbook on Citizen Engagement: Beyond Consultation, no. March. 2008.

[7] A. Bassler, K. Brasier, N. Fogle, and R. Taverno, "Developing Effective Citizen Engagement: A How-To Guide for Community Leaders," Pennsylvania, 2008.

[8] G. Rowe and L. J. Frewer, "A typology of public engagement mechanisms," Sci. Technol. Hum. Values, vol. 30, no. 2, pp. 251-290, 2005, doi: 10.1177/0162243904271724.

[9] D. of E. and S. A. D. for P. A. and D. Management, "UN E-Government Survey 2008 : From E-Government to Connected Governance,” New York, 2008. 